\title{
IDENTIFIKASI VARIETAS KENTANG "SUPERJOHN” BERDASARKAN PENANDA RAPD (Random Amplified Polymorphic DNA)
}

\section{IDENTIFICATION OF "SUPERJOHN" POTATOES (Solanum tuberosum L) BASED ON RAPD (Random Amplified Polymorphic DNA) MARKER}

\author{
Runtunuwu D.S', J.E.X. Rogi², dan J.H. Palendeng ${ }^{3}$ \\ ${ }^{1}$ Lab. Genetika dan Pemuliaan Tanaman, ${ }^{2}$ Lab. Ekosistem dan Modeling Tanaman Fak. Pertanian Universitas \\ Sam Ratulangi Manado, dan ${ }^{3}$ Program Pascasarjana Unsrat. \\ e-mail: semueldr@gmail.com.
}

\begin{abstract}
Identification using morphological characters has time consuming. Currently, identification using molecular markers has now been popular due to rapid, saving time and more precisely. Superjohn potato variety has been cultivated in North Sulawesi. However, the Superjohn potato variety has not been characterized using molecular markers. This research was aiming to identify "Superjohn" potato based on RAPD (Random Amplified Polymorphic DNA) markers. The research was conducted in field and laboratory. Field research was performed by taking some young leaves from "Superjohn", Granola, and Atlantic variety from the field. Identification using molecular marker was conducted at laboratory. Nine RAPD primers were used to identify the superjohn variety. The nine primers were OPA-1, OPA-2, OPA-3, OPA-4, OPA-5, OPA-7, OPA-9, OPA-10, and OPO-1. The molecular identification revealed that "Superjohn" variety was different with Granola and Atlantic. OPA-9 900 primer could be used for identification "Superjohn" variety while OPA-101000 primer was suitable for identification Granola variety.
\end{abstract}

Keywords: Potatoes, variety, "Superjohn", Granola, Atlantic, and RAPD

\begin{abstract}
ABSTRAK
Penelitian ini dilakukan untuk mengidentikasi kentang "Superjohn" berdasarkan penanda RAPD (Random Amplified Polymorphic DNA). Penelitian dilakukan di lapangan dan laboratorium. Penelitian lapangan dilakukan dengan mengambil beberapa daun muda dari varietas kentang "Superjohn", Atlantik dan Granola. Kemudian analisis DNA dilakukan di laboratorium menggunakan analisis RAPD. Berdasarkan penanda RAPD ternyata kentang "Superjohn" berbeda dari kentang Granola dan kentang Atlantik. Penanda RAPD OPA- $9_{700}$ dapat digunakan untuk mengidentifikasi kentang "Superjohn" dan penanda RAPD OPA-10 1000 dapat digunakan untuk mengidentifikasi kentang Granola.

Kata kunci: Kentang, varietas, Superjohn, Granola, Granola, RAPD
\end{abstract}

Eugenia Volume 17 No. 1 April 2011 


\section{PENDAHULUAN}

Kentang "Superjohn" merupakan varietas unggul lokal yang spesifik lokasi. Kentang ini sudah lama dibudidayakan oleh petani di Kecamatan Modoinding Kabupaten Minahasa Selatan, dan sekarang penyebarannya sudah meliputi hampir seluruh kawasan Modassi (Modoinding, Modayag dan Passi). Rata-rata produksi kentang "Superjohn" dengan teknologi yang diterapkan petani berkisar antara $13-17$ ton/ha. Namun demikian, kentang ini memiliki potensi produksi yang cukup tinggi yaitu 25 ton/ha, dengan asumsi perhitungan jarak tanam $80 \times 20 \mathrm{~cm}$ dan produksi per tanaman $0,4 \mathrm{~kg}(4-5$ umbi) (Palendeng, 2010).

Kentang "Superjohn" telah dipasarkan di beberapa daerah di Indonesia Timur, seperti: Sulawesi Tengah, Sulawesi Selatan, Gorontalo, Maluku, Maluku Utara, Papua, Balikpapan, Samarinda. Namun masalahnya adalah kentang ini belum dilepas dan disertifikasi. Syarat yang harus dipenuhi untuk pelepasan suatu varietas adalah silsilah dan cara mendapatkannya jelas, tersedia diskripsi yang lengkap dan jelas, dapat menunjukkan keunggulan terhadap varietas pembanding, seragam, stabil dan mudah dibedakan dari varietas yang sudah dikenal (Deptan, 2004).

Kentang merupakan tanaman $n$ a tive daerah pengunungan Andes di Amerika Selatan. Tanaman ini diperkirakan telah dibudidayakan sejak tahun 500 SM. Penjelajah Spanyol memperkenalkan tanaman ini ke Eropa dan berdasarkan catatan yang ada, kentang mulai dibudidayakan sebagai tanaman pangan sejak tahun 1570 (Witono Adiyoga, dkk. 2004) .Hasil penelusuran tentang asal usul kentang "Superjohn", ternyata kentang merupakan hasil seleksi massa positif dari kentang varietas Granola yang dilakukan oleh seorang guru, yang juga sebagai petani kentang di Desa Makaaruyen Kecamatan Modoinding bernama Johne Walukow. Pada saat menanam kentang tersebut, Bapak Johne melihat ada satu tanaman yang lebih tinggi dan lebih rimbun dibandingkan dengan tanaman lainnya, dan ternyata umurnya lebih panjang dari tanaman lainnya.
Setelah dipanen, ternyata umbi yang dihasilkan oleh tanaman tersebut lebih besar dibandingkan dengan tanaman lainnya. Umbi-umbi yang dipanen dari satu tanaman ini ditanam lagi secara terpisah dan tanamannya tetap lebih tinggi dan lebih rimbun, serta umbinya tetap besar. Selanjutnya tanaman ini berkembang menjadi banyak dan tersebar ke petani lainnya dan oleh petani di daerah ini, tanaman ini dinamakan kentang "Superjohn".

Oleh karena itu perlu dilakukan identifikasi berdasarkan penanda molekuler untuk membuktikan apakah benar kentang "Superjohn" sama dengan kentang Granola atau berbeda menggunakan analisis RAPD (Random Amplified Polymorphic DNA). Kalau kentang "Superjohn" secara genetik sama dengan kentang Granola maka kentang ini tidak dapat dilepas sebagai suatu varietas baru, sebaliknya kalau ternyata kentang ini berbeda dengan kentang Granola maka tentunya kentang "Superjohn" dapat dilepas sebagai suatu varietas baru.

Penanda RAPD merupakan salah satu penanda molekuler yang dapat digunakan untuk menganalisis keragaman genetik (Lengkong dan Runtunuwu, 2005; Novarianto $d k k, 2007$ ), maupun mengidentifikasi antar dan dalam varietas tanaman (Bambang Sriyadi $d k k, 2001)$. Keunggulan penanda molekuler ini adalah hasilnya tidak dipengaruhi oleh lingkungan.

Penelitian ini dilakukan untuk mengidentifikasi kentang "Superjohn" menggunakan analisis Random Amplified Polymorphic DNA (RAPD). Apakah kentang "Superjohn" berbeda atau sama dengan kentang Granola?.

\section{METODE PENELITIAN}

Penelitian ini dilakukan di Lapangan dan di Laboratorium Bioteknologi Universitas Brawijaya Malang selama kurang lebih 3 bulan.

Sampel daun tanaman kentang "Superjohn", Granola dan Atlantik di ambil dari pertanaman di Desa Mokobang Kecamatan Modoinding Kabupaten Minahasa Selatan dan Desa Noongan Kecamatan Langowan Kabupaten Minahasa, yang ditanam sesuai dengan prosedur 
pelepasan varietas. Dipilihnya kentang Granola adalah untuk membuktikan apakah kentang "Superjohn" adalah varietas baru, sedangkan kentang Atlantik sebagai pembanding.

Alat utama yang digunakan adalah UV/Visible Spectrophotometer Ultrospec 3300pro, Thermocycler Gene Amp PCR System 2700 Apped Biosystems, Elektroforesis gel, UV transluminator dan Geldoc.

Penelitian ini dilakukan di lapangan dan di laboratorium. Penelitian di lapangan dilakukan untuk mengambil sampel daun tanaman kentang dan pengambilan data iklim. Setiap varietas diambil 3 tanaman sebagai contoh. Selanjutnya analisis DNA dilakukan di laboratorium. Penentuan sampel tanaman yaitu yang memiliki kriteria pertumbuhan sehat, dan daun yang masih muda. Daun selanjutnya dimasukkan kedalam plastik. Daun yang sudah berada dalam plastik kemudian dimasukkan kedalam "coolbox" untuk selanjutnya dianalisis di laboratorium, dengan prosedur sebagai berikut :

\section{Isolasi DNA}

Isolasi DNA total dilakukan berdasarkan Rohde et al. (1995) yang telah dimodifikasi oleh Novarianto, dkk. (2007). Daun muda tanaman kentang seberat $1 \mathrm{~g}$ digerus bersama $10 \mathrm{ml}$ buffer lisis $(100 \mathrm{mM} \mathrm{HCl} \mathrm{pH} \mathrm{8,} \mathrm{1,4} \mathrm{M} \mathrm{Nacl,} \mathrm{20mM} \mathrm{EDTA,}$ $20 \%$ CTAB, 0,2 \% $\beta$ merkaptoetanol ditambahkan pada saat digunakan lalu dimasukkan kedalam tabung sentrifus $15 \mathrm{ml}$. Setelah diinkubasi selama 60 menit pada $60^{\circ} \mathrm{C}$, larutan yang mengandung DNA dikoleksi dengan disentrifus pada kecepatan $10.000 \mathrm{rpm}$ selama 15 menit lalu diekstraksi dengan klorofom sebanyak 2 kali. Selanjutnya DNA dipresipitasi dengan menambahkan 0,8 volume isopropanol lalu diendapkan dengan disentrifus pada kecepatan $10.000 \mathrm{rpm}$ selama 15 menit. Kemudian DNA dibilas dengan alkohol $70 \%$ lalu dikeringkan. Terakhir DNA akan dilarutkan dengan mili-Q water steril sebanyak $200 \mu$ l.

Konsentrasi DNA diukur menggunakan UV/Visible Spectrophotometer Ultrospec 3300 pro yang ditentukan berdasarkan nilai absorbansi A260, nilai $\mathrm{A} 260=$ setara dengan $50 \mu \mathrm{g} D N A / m l$.
Sedangkan kemurniannya ditentukan berdasarkan A260/A280 = 1,8 - 2,0 (Sambrook, Fritch, and Maniatis, 1989).

\section{Amplifikasi PCR}

Amplifikasi PCR DNA dilakukan dengan menggunakan mesin Thermocycler Gene Amp PCR System 2700 Applied Biosystem dengan volume reaksi PCR sebanyak $25 \mu$ template DNA. Kondisi amplifikasi PCR yang digunakan : 1) Pra PCR $94^{\circ} \mathrm{C} / 5$ menit, 2) Denaturasi $94^{\circ} \mathrm{C} / 1$ menit, 3) Pelekatan primer $37^{\circ} \mathrm{C} / 1$ menit, 4) Pemanjangan DNA $72^{\circ} \mathrm{C} / 2$ menit. Primer yang digunakan untuk mengamplifikasi DNA total tanaman kentang sebanyak sembilan primer (Tabel 1).

\section{Elektroforesis DNA}

DNA hasil amplifikasi PCR setelah ditambah dengan $5 \mu \mathrm{l}$ bromofenol blue dielektroforesis pada $70 \mathrm{~V}$ selama 2 jam dalam $1,5 \%$ gel agarosa lalu diwarnai dengan etidium bromide selama 15 menit. Pita DNA hasil amplifikasi selanjutnya diamati diatas UV transluminator dan dilanjutkan dengan pemotretan menggunakan geldoc.

\section{Analisis Data}

Sidik jari DNA yang diamati diatas UV transluminator diterjemahkan dalam data biner dengan ketentuan nilai 0 (nol) untuk yang tidak ada pita DNA dan 1 (satu) untuk yang ada pita DNA, serta ukuran pita DNA berdasarkan penanda ukuran DNA $1 \mathrm{~kb}$ ladder. Selanjutnya berdasarkan hasil foto pita DNA hasil amplifikasi PCR tiap primer, dianalisis sidik jari DNA diantara varietas kentang "Superjohn", Granola, dan Atlantik.

\section{HASIL DAN PEMBAHASAN}

Identifikasi suatu varietas tanaman dapat dilakukan menggunakan penanda. Penanda adalah karakter yang dapat diturunkan dan dapat berasosiasi dengan genotipe tertentu Asiedu dan Mujeeb (1989). 
Tabel 1. Primer dan Urutan Basa Nukleotida

(Table 1 The Sequence Nucleotide of the Primer)

\begin{tabular}{ccc}
\hline No. & Primer & Urutan Basa Nukleotida \\
\hline 1. & OPA-1 & CAG GCC CTT C \\
2. & OPA-2 & TGC CGA GCT G \\
3. & OPA-3 & AGT CAG CCA C \\
4. & OPA-4 & AAT CGG GCT G \\
5. & OPA-5 & AGG GGT CTT G \\
6. & OPA-7 & GAA ACG GGT G \\
7. & OPA-9 & GGG TAA CGC C \\
8. & OPA-10 & GTG ATC GCA G \\
9. & OPO-1 & TCA GAG CGC C
\end{tabular}

Keterangan: 1. OPA = Operon Kit A; 2). OPO = Operon Kit O, USRT = Unsrat; $A=A d$ denin, $T=$ Timin, $G=$ Guanin, dan C $=$ Sitosin.

Penanda dapat digolongkan atas penanda morfologis, sitologis atau penanda molokuler (Melchinger, 1990). Penanda molekuler dibedakan atas penanda protein dan DNA, yang dilihat melalui polimorfisme pola pita isoenzim dan DNA (Aswidinoor, 1991). Penanda molekuler lebih akurat dibandingkan dengan penanda morfologi, karena penanda ini tidak dipengaruhi oleh lingkungan.

Dari sebanyak sembilan praimer Operon yang digunakan untuk mengamplifikasi DNA total tiga varietas tanaman kentang, yaitu : 1) "Superjohn", 2) Granola, dan 3) Atlantik, ternyata jumlah total pita DNA yang dihasilkan setiap praimer berkisar antara 2 sampai dengan 6 pita DNA atau karakter (Tabel 1).

Selanjutnya berdasarkan pita-pita DNA yang dihasilkan tersebut, dilihat pola-pola pita DNA berdasarkan jumlah dan ukuran pita DNA-nya. Kalau jumlah dan ukuran pita DNA-nya sama (monomorfik), maka secara genetik kentang yang diidentifikasi sama, sebaliknya kalau jumlah dan ukuran pita DNA-nya berbeda (polimorfik) maka secara genetik kentang yang diidentifikasi berbeda.

Berdasarkan pola pita DNA yang dihasilkan, ternyata lima primer diantaranya adalah monomorfik (polanya sama diantara kentang "Superjohn", kentang Granola dan kentang
Atlantik), yaitu: 1) Praimer OPA-1, 2) Praimer OPA2, 3) Praimer OPA-4, 4) Praimer OPA-5, dan Praimer OPO-1. Sedangkan empat praimer diantaranya adalah polimorfik (polanya berbeda diantara salah satu dari kentang "Superjohn", kentang Granola atau kentang Atlantik), yaitu: 1) Praimer OPA-3, 2) Praimer OPA-7, 3) Praimer OPA-9, dan 4) Praimer OPA-10 (Tabel 2).

Hasil amplifikasi praimer OPA-3 menunjukkan bahwa pola pita DNA kentang "Superjohn" sama dengan kentang Granola (monomorfik), dan dengan kentang Atlantik adalah berbeda (polimorfik) (Gambar 1). Kentang "Superjohn" dan kentang Granola sama-sama mempunyai $5(100 \%)$ pita DNA yang sama ukurannya, sedangkan kentang Atlantik hanya mempunyai $3(64 \%)$ pita DNA yang sama ukurannya dengan kentang "Superjohn" dan kentang Granola. Jadi berdasarkan hasil amplifikasi praimer OPA-3, ternyata kentang "Superjohn" sama dengan kentang Granola, tapi dengan kentang Atlantik berbeda. Kemudian, hasil amplifikasi praimer OPA-7 menunjukkan bahwa pola pita DNA kentang "Superjohn" sama dengan kentang Granola (monomorfik), dan dengan kentang Atlantik adalah berbeda (polimorfik) (Gambar 2). 
Tabel 2. Jumlah Total Pita DNA dan Pola Pita DNA Tanaman Kentang "Superjohn", Granola dan Atlantik (Table 2. Total band of the DNA and DNA banding pattern of the potatoe var. "Superjohn, Granola, and Atlantic)

\begin{tabular}{lllll}
\hline No. & Praimer & Urutan Basa Nukleotida & $\begin{array}{l}\text { Jumlah Total Pita } \\
\text { DNA }\end{array}$ & $\begin{array}{l}\text { Pola Pita } \\
\text { DNA }\end{array}$ \\
\hline 1. & OPA-1 & CAG GCC CTT C & 4 & Monomorfik \\
2. & OPA-2 & TGC CGA GCT G & 5 & Monomorfik \\
3. & OPA-3 & AGT CAG CCA C & 5 & Polimorfik \\
4. & OPA-4 & AAT CGG GCT G & 3 & Monomorfik \\
5. & OPA-5 & AGG GGT CTT G & 3 & Monomorfik \\
6. & OPA-7 & GAA ACG GGT G & 3 & Polimorfik \\
7. & OPA-9 & GGG TAA CGC C & 3 & Polimorfik \\
8. & OPA-10 & GTG ATC GCA G & 2 & Polimorfik \\
9. & OPO-1 & TCA GAG CGC C & 6 & Monomorfik \\
\hline
\end{tabular}

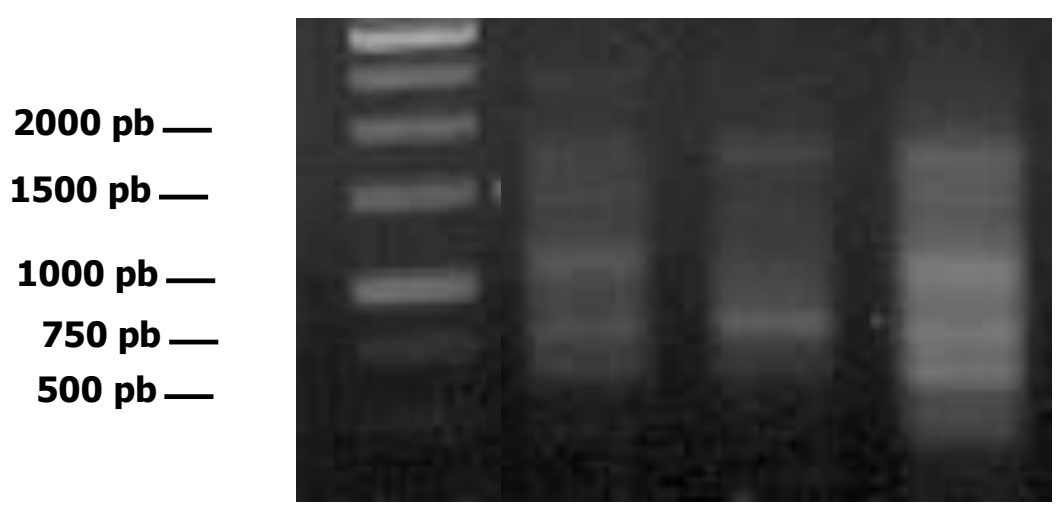

Gambar 1. Pola Pita DNA Kentang: "Superjohn" (2), Atlantik (3) dan Granola (4) Hasil Amplifikasi Praimer OPA3. Ket. $1=$ Penanda ukuran $1 \mathrm{~kb}$ DNA ladder, $\mathrm{pb}=$ pasangan basa

(Figure 1. Pattern Ribbon Of DNA Potato :Superjohn" (2), Atlantic (3) and Granola (4) Result of Amplifikasi Praimer OPA-3. Ket. 1 = Penanda Size Measure 1 DNA Ladder kb, $p b=$ Couple Of Basa

Kentang "Superjohn" dan Granola mempunyai $3(100 \%)$ pita DNA yang sama ukurannya, sedangkan dengan kentang Atlantik hanya mempunyai $2(66,67 \%)$ pita DNA yang sama ukurannya. Jadi berdasarkan hasil amplifikasi praimer OPA-7, ternyata kentang "Superjohn" sama dengan kentang Granola, tapi dengan kentang Atlantik berbeda.

Hasil amplifikasi primer OPA-9 menunjukkan pola pita DNA kentang "Superjohn" berbeda (polimorfik) dengan pola pita DNA kentang Granola dan Atlantik (Gambar 3). Kentang
"Superjohn" mempunyai 1 pita DNA yang berbeda ukurannya dengan kentang Granola dan kentang Atlantik, yaitu pita DNA yang berukuran $700 \mathrm{bp}$, sehingga pita DNA ini dapat dijadikan sebagai pembeda antara kentang "Superjohn" dengan kentang Granola serta kentang Atlantik. Pita DNA ini dinamakan sebagai penanda RAPD OPA- $9_{700}$. Akhirnya, hasil amplifikasi primer OPA-10 pola pita DNA kentang "Superjohn" berbeda (polimorfik) dari kentang Granola, tapi sama (monomorfik) dengan kentang Atlantik (Gambar 4). 


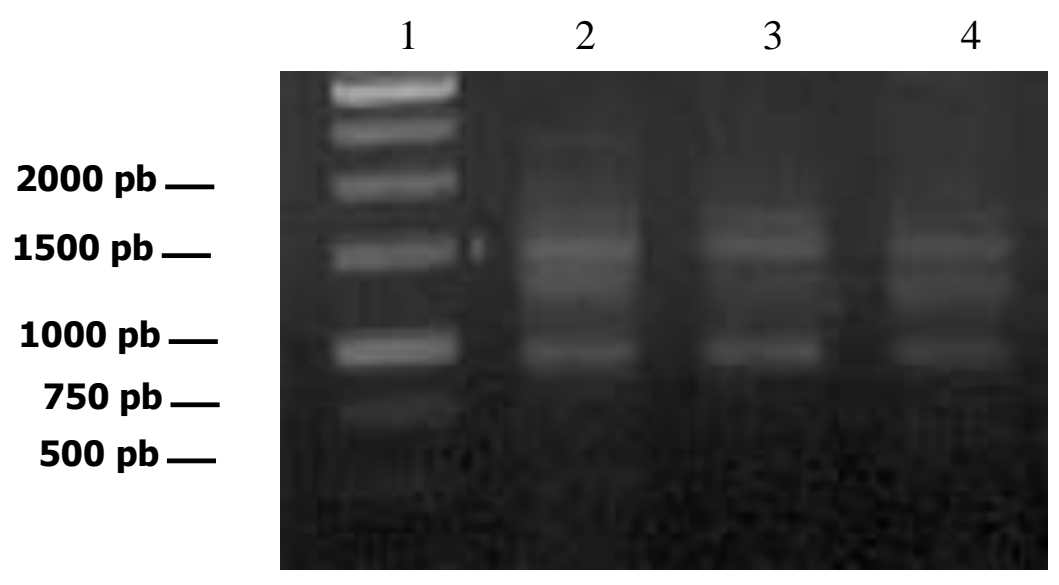

Gambar 2. Pola Pita DNA Kentang: "Superjohn" (2), Atlantik (3), dan Granola (4) Hasil Amplifikasi Praimer OPA-7.Ket. $1=$ Penanda ukuran $1 \mathrm{~kb}$ DNA ladder, $\mathrm{pb}=$ pasangan basa

(Figure 2. Pattern Ribbon Of DNA Potato :Superjohn" (2), Atlantic (3) and Granola (4) Result of Amplifikasi Praimer OPA-7. Ket. $1=$ Penanda Size Measure 1 DNA Ladder kb, $p b=$ Couple Of Basa

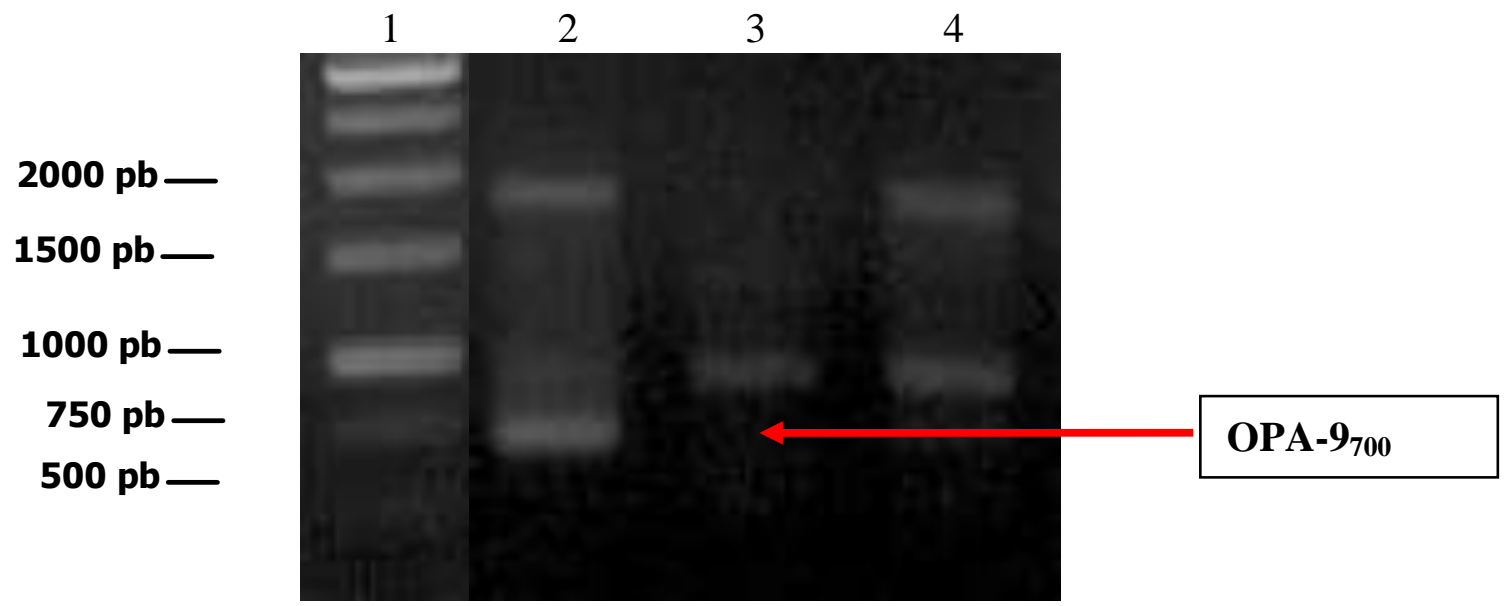

Gambar 3. Pola Pita DNA Kentang: "Superjohn" (2), Atlantik (3), dan Granola (4) Hasil Amplifikasi Praimer OPA-9. Ket. $1=$ Penanda ukuran $1 \mathrm{~kb}$ DNA ladder, pb= pasangan basa

(Figure 3. Pattern Ribbon Of DNA Potato :Superjohn" (2), Atlantic (3) and Granola (4) Result of Amplifikasi Praimer OPA-9. Ket. 1 = Penanda Size Measure 1 DNA Ladder kb, $p b=$ Couple Of Basa)

Kentang Granola mempunyai sebuah pita DNA berukuran 1000 bp yang tidak terdapat baik pada kentang "Superjohn" dan kentang Atlantik, sehingga pita DNA ini dapat dijadikan sebagai pembeda antara kentang Granola dengan kentang "Superjohn" serta kentang Atlantik. Pita DNA ini dinamakan sebagai penanda RAPD OPA-101000. Berdasarkan penanda RAPD yang ditemukan, maka ternyata penanda RAPD dapat membedakan kentang "Superjohn" dari kentang Granola dan kentang Atlantik. Hasil yang serupa ditemukan juga pada tanaman tea, penanda RAPD dapat membedakan antar-varietas koleksi plasma nutfah tea di China (Chen dan Yamaguchi, 2005), pada tanaman kapas penanda RAPD dapat mengelompokkan kultivar kapas yang diploid dan kultivar kapas tetraploid (Rana and Bhat, 2005), pada tanaman kelapa, penanda RAPD OB17 375 dapat membedakan kelapa Genjah Salak yang rentan terhadap penyakit GB Phytophthora dari kelapa GSK yang tahan terhadap penyakit tersebut (Runtunuwu, 2000). Selanjutnya berdasarkan penanda RAPD OPB $01_{800}$, OPB $01_{1500,}$, OPB $07_{500}$, OPC 13500, OPC 131100, OPC 131400, SC-10 48 1300, 
dan SC-10 56 $6_{600}$ dapat digunakan untuk membedakan tanaman teh yang tahan terhadap penyakit cacar karena penanda ini berpaut kuat dengan gen pengendali ketahanan tanaman teh terhadap penyakit tersebut (Bambang Sriyadi $d k k$., 2001).

Hasil penelitian ini menunjukkan bahwa penanda RAPD OPA- $9_{700}$ dapat membedakan kentang "Superjohn" dari kentang Granola dengan kentang Atlantik, sedangkan penanda RAPD OPA101000 dapat membedakan kentang Granola dari kentang "Superjohn" dan kentang Atlantik. Selanjutnya berdasarkan penanda RAPD OPB $01_{800}$, OPB $01_{1500}$, OPB $07_{500}$, OPC $1_{500}$, OPC 131100, OPC 131400, SC-10 48 1300 , dan SC-10 56 600 dapat digunakan untuk membedakan tanaman teh yang tahan terhadap penyakit cacar karena penanda ini berpaut kuat dengan gen pengendali ketahanan tanaman the terhadap penyakit tersebut (Bambang Sriyadi $d k k$., 2001). Hasil penelitian ini menunjukkan bahwa penanda RAPD OPA- $9_{700}$ dapat membedakan kentang "Superjohn" dari kentang Granola dengan kentang Atlantik, sedangkan penanda RAPD OPA-10 1000 dapat membedakan kentang Granola dari kentang "Superjohn" dan kentang Atlantik. Dengan demikian kentang "superjohn" berbeda secara genetic dengan kentang granola bukan karena faktor lingkungan/iklim. Sebagai gambaran ikil di Modoinding bertipe A dan mempunyai suhu udara rata-rata $18.7-21.0{ }^{\circ} \mathrm{C}$ dengan radiasi rata-rata 17.0 - $19.8 \mathrm{MJ} / \mathrm{m}^{2} /$ hari serta kelembaban relatif 88.5 - $96.0 \%$ dan lama pemyinaran antara 5.2 6.8 jam.

Hasil analisis RAPD ini sejalan dengan penanda morfologi, yaitu daun kentang varietas Atlantik dan Granola berbentuk oval, sedangkan "Superjohn" agak bulat. Ukuran daun varietas Granola dan "Superjohn" lebih kecil dibandingkan dengan varietas Atlantik. Permukaan daun varietas Atlantik agak licin dibandingkan dengan varietas Granola dan "Superjohn". Kemudian urat utama daun varietas Atlantik berwarna hijau tua, sedangkan varietas Granola dan "Superjohn" berwarna hijau muda (Palendeng, 2010).

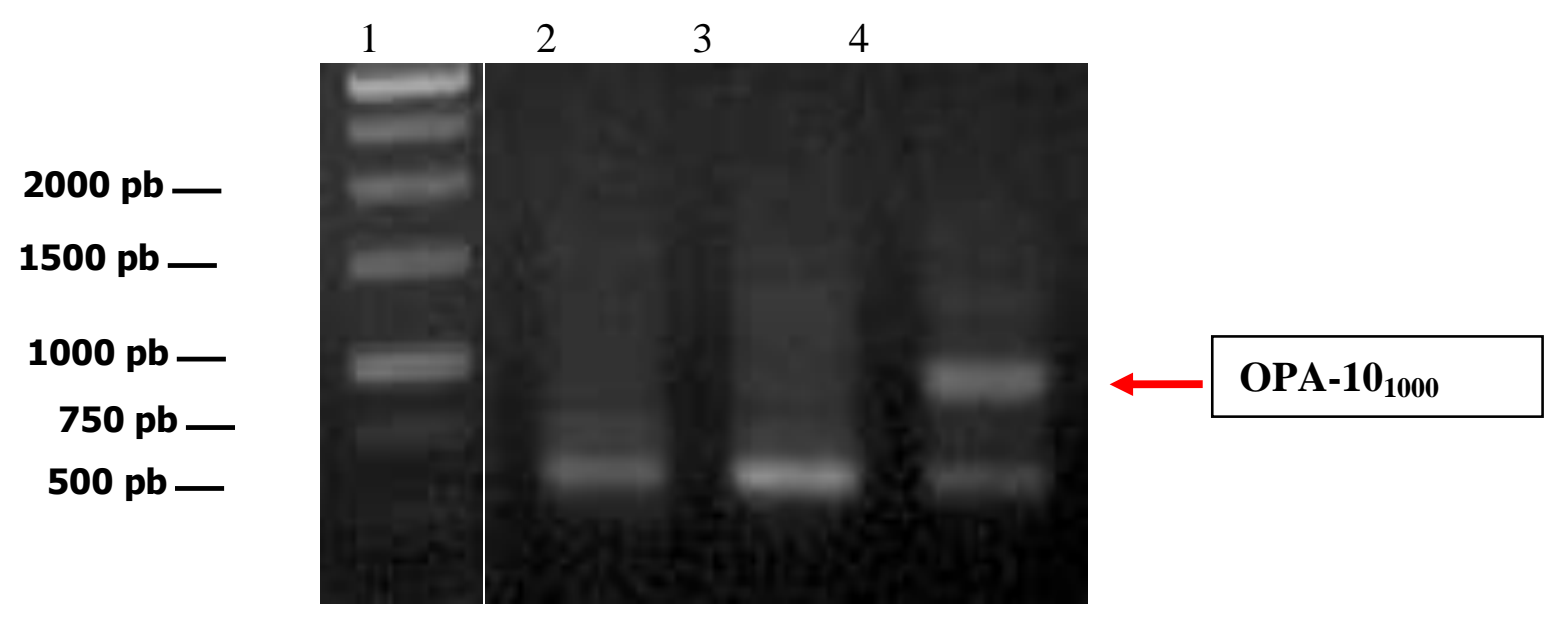

Gambar 4. Pola Pita DNA Kentang: "Superjohn" (2), Atlantik (3), dan Granola (4) Hasil Amplifikasi Praimer OPA-10. Ket. $1=$ Penanda ukuran $1 \mathrm{~kb}$ DNA ladder, pb= pasangan basa

(Figure 4. Pattern Ribbon Of DNA Potato :Superjohn" (2), Atlantic (3) and Granola (4) Result of Amplifikasi Praimer OPA-10. Ket. 1 = Penanda Size Measure 1 DNA Ladder kb, $p b=$ Couple Of Basa) 


\section{KESIMPULAN}

Berdasarkan hasil analisis RAPD (Random Amplified Polymorphic DNA), ternyata kentang "Superjohn" berbeda dari kentang varietas Granola dan varietas Atlantik. Penanda RAPD OPA- $9_{700}$ dapat digunakan untuk mengidentifikasi kentang "Superjohn" karena penanda RAPD ini spesifik terdapat pada kentang "Superjohn", sedangkan penanda RAPD OPA-10 1000 dapat digunakan untuk mengidentifikasi kentang Granola karena penanda RAPD ini spesifik terdapat pada kentang Granola.

\section{DAFTAR PUSTAKA}

Asiedu, R.N.T. dan A. Mujeeb-Kazi, 1989. Diagnostic Markers in Wheat Wide Crosses. p. 293 -299 .Seminar Sehari Hasil Hasil Penelitian IImu Hayati. 1998. Bogor.

Aswidinoor, H. 1991.dalam S. Haran dan N. Ansory Rekayasa Genetika. p. 96 - 186 Bioteknologi Pertanian II . PAU IPB Bogor.

Bambang Sriyadi, R. Setiamihardja, A. Baihaki, dan W. Astika. 2001. Identifikasi Pembeda RAPD yang berpautan dengan Gen Ketahanan Tanaman Teh terhadap Penyakit Cacar. Zuriat 12 (2): $49-57$.

Chen, L., and S. Yamaguchi. 2005. RAPD markers for discriminating tea germplasms at the inter-specific level in China. Plant Breeding 124, 404-409.

Departemen Pertanian. 2004. Peraturan Perbenihan Tanaman. Badan Benih Nasional Jakarta.

Lengkong, E.F. dan S.D. Runtunuwu. 2005. Penggunaan Penanda Molekuler Random Amplified Polymorphic DNA (RAPD) untuk Analisis Keragaman Genetik Kelapa West African Tall (WAT). Eugenia 11 (3) : 210 217.
Melchinger, A.E. 1990. Use Moleculer Marker in Breeding for Oligogenic Disease Resistance. Plant Breed 104: 1 - 9.

Palendeng, J. H. 2010. Analisis Keragaman Genetik Tanaman Kentang (Solanum tuberosum L) varietas "Superjohn", Granola, dan Atlantik berdasarkan Penanda RAPD (Randomly Amplified Polymorphic DNA). Tesis Program Pascasarjan UNSRAT.

Rohde, W.A. Kullaya,J. Rodrigues and E.Ritter. 1995. Genome Analysis of Cocos nucifera L. by PCR Amplification of Spacer Sequences Separating a Subset of Copialike EcoRI Repertitive Elements. J. Genet. Breed. 49 : 179-186.

Runtunuwu, S.D. 2000. Penanda Molekuler Ketahanan Tanaman Kelapa Terhadap Penyakit GB Phytophthora. Disertasi Program Pascasarjana IPB.

Rana, M. K. and K. V. Bhat. 2005. RAPD Markers for Genetic Diversity Study Among Indian Cotton Cultivars. Current Science 88 (12: 1956 - 1961.

Novarianto H., S. D. Runtunuwu, E.F. Lengkong, dan M. Singkoh. 2007. Studi Keragaman Pola Pita DNA dan Keseragaman Populasi Kelapa Genjah Salak (GSK) Berdasarkan Penanda RAPD. Eugenia 13 (1): 109 118.

Sambrook, J., E. F., Fritch, and T. Maniatis. 1989. Molecular Clonning . A Laboratory Manual. Cold Spring Harbor Lab. CHS. New York.

Witono Adiyoga, R. Suherman, T. Agoes Soetiarso, B. Jaya, B. Kukuh Udiarto, R. Rosliani, dan D. Mussadad. 2004. Profil Komoditas Kentang. Balai Penelitian Tanaman Sayuran. Puslitbang Hortikultura. Balitbang Pertanian, Deptan. 